\title{
PCB concentrations in plankton size classes, a temporal study in Marseille Bay, Western Mediterranean Sea
}

\author{
Marion Tiano $^{\mathrm{a}, \mathrm{b}}$, Jacek Tronczyński ${ }^{\mathrm{b}, *}$, Mireille Harmelin-Vivien ${ }^{\mathrm{a}}$, Céline Tixier ${ }^{\mathrm{b}}$, François Carlotti ${ }^{\mathrm{a}}$ \\ ${ }^{a}$ Aix Marseille Université, CNRS, Université de Toulon, IRD, MIO UM 110, 13288 Marseille, France \\ ${ }^{\mathrm{b}}$ IFREMER, Centre Atlantique, Ressources Biologique et Environnement (RBE), Unité Biogéochimie et Ecotoxicologie, Laboratoire LBCO, rue de l'Ile d'Yeu, \\ 43311 Nantes, Cedex 03, France
}

\section{A R T I C L E I N F O}

Article history:

Available online 18 October 2014

\section{Keywords:}

PCBs

Phytoplankton

Zooplankton

Bioaccumulation

Coastal

Bay of Marseille

\begin{abstract}
A B S T R A C T
PCB levels in plankton were investigated in the Bay of Marseille, Western Mediterranean Sea, between September 2010 and October 2011. Concentrations of PCB congeners (CB 18, CB 52, CB 101, CB 118, CB 138, СВ 153, СВ 180) were determined in three plankton size-classes (60-200, 200-500 and $500-1000 \mu \mathrm{m})$ together with different parameters: chlorophyll content, plankton dry-weight biomass, carbon and nitrogen stable isotope ratios and plankton-community structure. The $\sum \mathrm{PCB}_{7}$ concentrations ranged between 14.2 and $88.1 \mathrm{ng} \mathrm{g}^{-1} \mathrm{~d}$.w., for all size classes and all sampling periods. The results do not show the biomass dilution effect and indicate moderate but significant biomagnification with plankton trophic position estimated by $\delta^{15} \mathrm{~N}$ signatures. Equilibrium with water phase may notably contribute in controlling the PCB levels in the plankton. More generally, presented results imply that PCB accumulation in the plankton is an effect of abiotic and trophic complex interactions in the Bay of Marseille.
\end{abstract}

(c) 2014 Elsevier Ltd. All rights reserved.

\section{Introduction}

Polychlorinated biphenyls (PCBs) are persistent organic pollutants (POPs) now imbedded in natural biogeochemical cycles and present, in all environmental compartments in the earth (Johansson et al., 2006). A main concern with this group of POPs is related to its strong propensity to bioaccumulation living organisms and to biomagnify along terrestrial and marine food webs, over a wide range of trophic levels (Kidd et al., 1998; Fisk et al., 2001; Burreau et al., 2006). A number of studies provide data and evidence of the trophic transfer of PCBs especially in the upper trophic levels of marine predators, such as dolphins (Aguilar and Borrell, 2005), pinnipeds (Barron et al., 2003), killer whales (Ross et al., 2000) and sharks (Lu et al., 2014). Their diet appears to be the main pathway for these pollutants (Rasmussen et al., 1990; Catalan et al., 2004; Elliott et al., 2009), and marine fish contamination by PCBs is nowadays well documented (Rasmussen et al., 1990; Binelli and Provini, 2003; Catalan et al., 2004; Bodiguel et al., 2008; Harmelin-Vivien et al., 2012). However, the processes of PCBs transfer at the lowest trophic levels are relatively less well known. Especially the role of plankton, while recognized as a playing key role in the fate of PCBs on a global scale (for instance by

\footnotetext{
* Corresponding author. Tel.: +332403741 36; fax: +33240374075. E-mail address: Jacek.Tronczynski@ifremer.fr (J. Tronczyński).
}

controlling their air-sea exchanges and bottom fluxes; Dachs et al., 1999; Nizzetto et al., 2012), is still a matter of scientific discussion as far as the mechanisms of PCBs uptake by plankton are concerned. There is no full agreement whether PCBs assimilation by plankton is dominated by partition equilibrium processes or, especially in zooplankton, if it may be mainly related to prey-predator relationships (Berglund et al., 2000; Borgå et al., 2004; Sobek et al., 2006; Magnusson et al., 2007; Hallanger et al., 2011). It also appears that such a relation within plankton communities is difficult to demonstrate in many field studies, chiefly because of difficulties of plankton species separation and the need of a relatively large amount of samples for chemical analysis.

The Gulf of Lion, in the Western Mediterranean Sea, is recognized as a relatively productive marine ecosystem, with high social and economic values and an area under high anthropogenic pressures (e.g. Lleonart and Maynou, 2003). The levels of PCBs in the sediments and biota of the GoL, are high when compared with other Mediterranean regions (Gomez-Gutierrez et al., 2007; Bodiguel et al., 2008). The Rhône River watershed is a highly industrialized and urbanized region discharging the most important loads of chemical contaminants to the GoL (Radakovitch et al., 2008). On the other hand, $90 \%$ of the activities of French Mediterranean fisheries take place in this region, where the European hake (Merluccius merluccius) is the largest commercial fish species in the demersal landings (Aldebert et al., 1993). Recent studies investigated the PCB transfer in the food-web of the European hake in 
the Gulf of Lion (Bodiguel et al., 2008, 2009; Harmelin-Vivien et al., 2012). Their results show that levels of PCB are higher in the hakes of GoL than in the Bay of Biscay and indicated that the small pelagic fish such as anchovy (Engraulis encrasicolus) and sardine (Sardina pilchardus) represent a main pathway of contaminants to higher trophic levels of marine food-web in the Western Mediterranean Sea. Furthermore, the need for more data in the vicinity of large cities "hot spots" and better understanding of their role in contaminants transfer to the coastal food webs were also recently underlined (Durrieu de Madron et al., 2011).

In the present paper are examined the results concerning the study of plankton contamination by PCBs in the Bay of Marseille. The Bay of Marseille, located at the eastern border of the GoL, represents an urban hot spot area, where chemical contamination is high and environmental conditions relatively well known. In this area, the urban sewage plant discharges domestic and industrial wastewaters in the south of the bay, and the port activities are relatively intense (Sauzade et al., 2007, 2009; Pinazo et al., 2013). The region is naturally exposed to strong north-northwest (Mistral) and south-southeast winds, which may induce the re-suspension of sediments into the water column (Vousdoukas et al., 2011). Furthermore, the circulation of water masses is well known (Fraysse et al., 2013), and a biogeochemical survey has also been conducted at the SOMLIT/SOFCOM observatory station since 1995 (Gregori et al., 2001).

We have thus conducted regular sampling of plankton at SOMLIT/SOFCOM station in the Bay of Marseille, in order, (i) to assess the PCB seasonal variations and accumulation in the different size classes of plankton, and (ii) to link these variations of PCB levels with the environmental and biological factors which might influence their bioaccumulation in the plankton in the Bay of Marseille. In the present paper we give results of only the seven indicator PCBs (CB28, CB52, CB101, CB118, CB138, CB153 and CB180). The environmental parameters include meteorological conditions, the Huveaune flow, a small river discharging directly into the Bay, and some biochemical and biological parameters of the plankton: Chlorophyll $a$ concentration, ${ }^{15} \mathrm{~N}$ and ${ }^{13} \mathrm{C}$ stable isotope signatures, plankton biomass and the identification of plankton composition.

\section{Material and methods}

2.1. Plankton sampling and meteorological data collection, plankton size class separation, biomass determination and pigment analysis

The sampling was conducted in the Bay of Marseille (NW Mediterranean Sea) from September 2010 to October 2011 (Table 1, Fig. 1). Plankton (phytoplankton and zooplankton) was collected according to COSTAS (Contaminants in the trophic system: phytoplankton, zooplankton, anchovy, sardine) project protocols with a net of $60 \mu \mathrm{m}$ mesh size by repeated multiple horizontal short duration tows (5-10 min) carried out between 10 and $15 \mathrm{~m}$ depth, as CTD profiles revealed no clear maximum of chlorophyll depth. The sampling site is located at the shallow depth and the water column at this area is well-mixed all year-round and considered as

Table 1

Date, geographic location and depth at sampling site.

\begin{tabular}{lllll}
\hline Station & Date & Latitude & Longitude & Depth $(\mathrm{m})$ \\
\hline S1 & $09 / 08 / 2010$ & $43^{\circ} 15.788 \mathrm{~N}$ & $5^{\circ} 17.280 \mathrm{E}$ & 44 \\
S2 & $11 / 16 / 2010$ & $43^{\circ} 15.788 \mathrm{~N}$ & $5^{\circ} 17.280 \mathrm{E}$ & 44 \\
S3 & $12 / 14 / 2010$ & $43^{\circ} 15.788 \mathrm{~N}$ & $5^{\circ} 17.280 \mathrm{E}$ & 44 \\
S4 & $01 / 23 / 2011$ & $43^{\circ} 13.712 \mathrm{~N}$ & $5^{\circ} 15.527 \mathrm{E}$ & 60 \\
S5 & $04 / 15 / 2011$ & $43^{\circ} 13.869 \mathrm{~N}$ & $5^{\circ} 15.655 \mathrm{E}$ & 55 \\
S6 & $06 / 07 / 2011$ & $43^{\circ} 15.788 \mathrm{~N}$ & $5^{\circ} 17.280 \mathrm{E}$ & 44 \\
S7 & $10 / 11 / 2011$ & $43^{\circ} 15.788 \mathrm{~N}$ & $5^{\circ} 17.280 \mathrm{E}$ & 44 \\
\hline
\end{tabular}

homogeneous. This was also shown by a 3D coupled physical-biogeochemical model of the Marseille area (Fraysse et al., 2013). The content of each tow was fractionated on a sieve column of 60,200 , 500,1000 and $2000 \mu \mathrm{m}$ mesh sizes. The $60-200 \mu \mathrm{m}$ size class was more representative of phytoplankton while the 200-500 and $500-1000 \mu \mathrm{m}$ size classes were representative of zooplankton. Sub-samples of each size fraction were stored frozen at $-20^{\circ} \mathrm{C}$ until further analyses (PCB, pigments, $\mathrm{C}$ and $\mathrm{N}$ stable isotope ratios).

A small sub-sample of the $60-200 \mu \mathrm{m}$ sized-fraction was fixed in lugol solution and sub-samples of higher sized-fractions were fixed in formaldehyde solution for plankton abundances and taxa determinations. The plankton biomass was determined by vertical tows of bongo net. The homogeneity of the water column resulted in the homogeneity of composition and biomass of the planktonic communities, allowing comparison of vertical and horizontal sampling tows. The content of the bongo net collector was also fractionated on the sieve column and each size class was recovered on pre-combusted and pre-weighed Whatman GF/F filter. Filters were dried over night at $50{ }^{\circ} \mathrm{C}$ to constant dry weights for biomass determination. Meteorological data were obtained from www.meteociel.fr and Huveaune streamflow data from www.hydro.eaufrance.fr. The chlorophyll vertical water column profiles were determined by a CTD Sea-Bird Electronics profiler equipped with an in situ fluorimeter (Aqua Tracka 3, Chelsea Technologies Group, UK). The seawater was sampled with a Niskin bottle and 51 were filtered on Whatman GF/F filters for measuring chlorophyll a (chl-a) and phaeopigment (pheo) contents. Chl- $a$ was extracted in acetone and determined by fluorimetry according to the method described in Aminot and Kerouel (2004).

\section{2. $P C B$ analysis}

Polychlorinated biphenyl PCBs were analyzed according to the protocol described earlier (Munschy et al., 2004; Johansson et al., 2006). The analyses was done by high resolution gas chromatography (HRGC, GC3800, Varian) fitted with two electron capture detectors (ECD), using two columns of different polarities: a DB-5 (5\% phenyl-methylpolysiloxane) column of $60 \mathrm{~m} \times 0.25 \mathrm{~mm}$ (film thickness $0.25 \mu \mathrm{m}$ ), and an HT8 (8\% phenyl-polysiloxane-carborane) column of $50 \mathrm{~m} \times 0.25 \mathrm{~mm}$ (film thickness $0.25 \mu \mathrm{m}$ ). Hydrogen is the carrier gas at a linear velocity of $27.6 \mathrm{~cm} \mathrm{~s}^{-1}$. The oven is programmed from $100^{\circ} \mathrm{C}$ maintained for $1 \mathrm{~min}$ before increasing the temperature to $180^{\circ} \mathrm{C}$ at a rate of $7{ }^{\circ} \mathrm{C} / \mathrm{min}$, followed by a second increase to $280^{\circ} \mathrm{C}$ at $3{ }^{\circ} \mathrm{C} / \mathrm{min}$ with a final hold of $20 \mathrm{~min}$. The detector temperature is $300^{\circ} \mathrm{C}$ and the nitrogen make up flow is adjusted to $25 \mathrm{ml} / \mathrm{min}$. All CB congeners are quantified on both columns, and the reported result is chosen for each non co-eluting congener on the appropriate column. Concentrations are calculated by external multi-level calibration regression in the linear range of the response of the detector. Whenever necessary, two calibration curves are used to offset the nonlinear response of the ECD detector, i.e., the first in the range of $2-75 \mathrm{pg}$ and the second of $75-250 \mathrm{pg}$ of injected individual congeners. The standards added before the extraction are used as recovery surrogates, but concentrations are not corrected for recovery. The overall internal QA/QC procedures include laboratory and field blanks, analyses of replicate samples for precision determination, the use of internal recovery standards added to each sample prior to extraction, and analyses of Reference Materials (SRM 2977 NIST). The samples collected were treated in a clean on-board laboratory. The frozen samples were transported into clean-laboratory facilities (class 1000 , iso 6) and further treated in the uncontaminated conditions. The field and procedural blanks were run for each bunch of 4-6 samples. All analyzed congeners concentrations in the blank samples were below limit of detection ( $\mathrm{LOD}=3^{*}$ sd of blank) and 


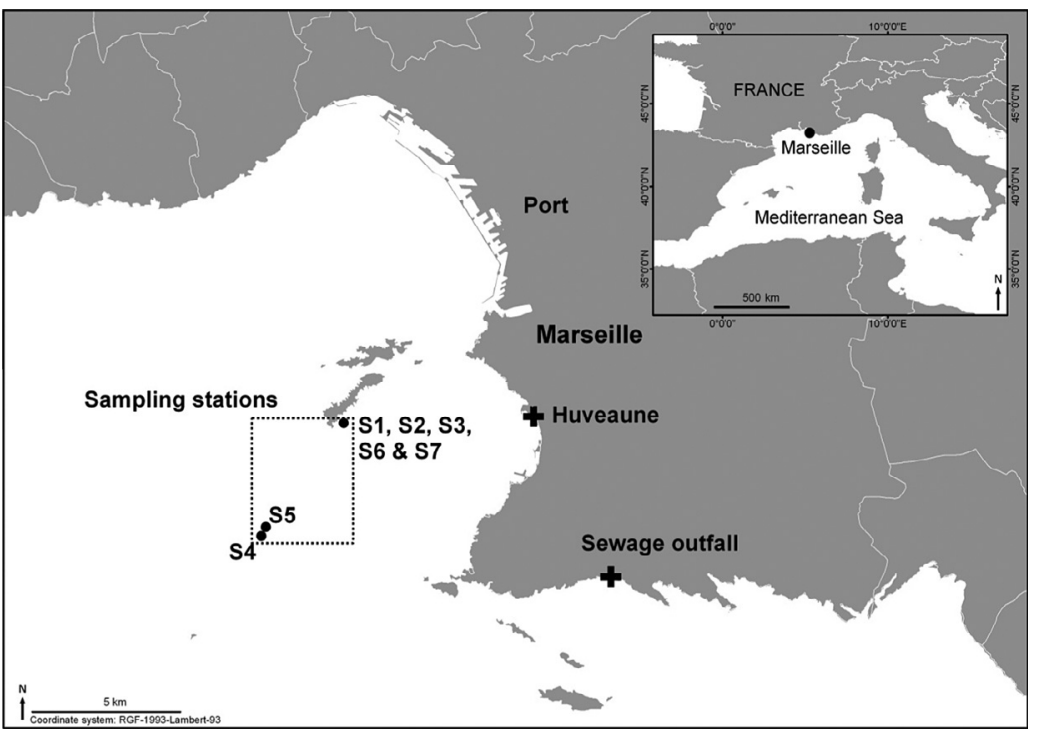

Fig. 1. Sampling location in the Bay of Marseille.

therefore the results were not corrected for any blank value. The laboratory proficiency for the analysis of $\mathrm{CB}$ is also evaluated through participation in the QUASIMEME (Quality Assurance of Information for Marine Environmental Monitoring in Europe) inter-comparison exercises. Overall accuracy was within $89-101 \%$ of certified values $(n=11)$. Relative standard deviation was better than $\pm 15 \%$ for all PCB congeners considered in this study. Average recovery of standards (CB30, CB198 and CB209) was $88.7 \pm 22.5 \%$, $92.1 \pm 24.1$ and $95.1 \pm 32.4 \%$ respectively

\subsection{Nitrogen and carbon stable isotope ratios}

$\delta^{13} \mathrm{C}$ and $\delta^{15} \mathrm{~N}$ determinations were conducted on two subsamples of each size fraction. A sub-sample without prior treatment was used for $\mathrm{N}$ stable isotope analysis. A second one, for carbon analysis, was acidified with a $10 \% \mathrm{HCl}$ solution, rinsed with distilled water and oven-dried at $40^{\circ} \mathrm{C}$ for $24 \mathrm{~h}$, to remove carbonates (Deniro and Epstein, 1978). ${ }^{13} \mathrm{C} /{ }^{12} \mathrm{C}$ and ${ }^{15} \mathrm{~N} /{ }^{14} \mathrm{~N}$ ratios were measured simultaneously, using an isotope ratio mass spectrometer (Europa Scientific ANCA-NT 20-20 stable isotope analyzer with an ANCA Solid/Liquid preparation module), which was operated in dual mode. The analytical precision was $0.2 \%$ for both $\mathrm{N}$ and $\mathrm{C}$ and was determined from internal standards analyzed along with the samples ( $1 \mathrm{mg}$ leucine prepared by freeze drying $50 \mu \mathrm{l}$ of a $20 \mathrm{mg} \mathrm{mL}^{-1}$ stock solution calibrated against "Europa flour" and IAEA standards N1 and N2). Isotope ratios were expressed as parts per thousand (\%o) differences from a standard reference material

$\delta X=\left[\frac{R_{\text {Sample }}}{R_{\text {reference }}}-1\right] \times 10^{3}$

where $X$ is ${ }^{13} \mathrm{C}$ or ${ }^{15} \mathrm{~N}$ and $R$ the corresponding ratio ${ }^{13} \mathrm{C} /{ }^{12} \mathrm{C}$ or ${ }^{15} \mathrm{~N} /{ }^{14} \mathrm{~N}$. The standard reference materials were Vienna PeeDee Belemnite for carbon and atmospheric $\mathrm{N}_{2}$ for nitrogen.

\subsection{Zooplankton taxa identification}

Zooplankton composition in samples for fractions larger than $200 \mu \mathrm{m}$ was performed using a Zooscan and Plankton Identifer software. Each sample was divided with Motoda splitter until reaching about two thousand individuals (Grosjean et al., 2004). It was then scanned and digitized with a resolution of 2400 dots per inch (dpi). Images were analyzed with the software Zooprocess, embedded in the image analysis software Image $\mathrm{J}$, which measured a total of 46 variables, including geometrical and optical characteristics of each individual. Automated classification, based on the supervised learning algorithms implemented in the free statistical pack TANAGRA, was applied with the software Plankton Identifer and a random forest algorithm. The algorithm used the 46 variables analyzed by Zooprocess and placed each individual in one of seven predefined plankton categories: "detritus" (including unidentified fragments), "copepods", "other crustaceans", "cladocerans", "chaetognaths", "appendicularians", "others". The quality of automated zooplankton analysis was checked by a visual verification based on the comparison of random selected images and taxonomic classification.

\subsection{Statistical analyses}

Independent one way ANOVAs were performed to assess the relation of time (month) and plankton size class with mean isotopic ratios and PCB concentrations. Post-hoc comparisons of means were performed with Tukey tests. When assumptions were not reached, non-parametric Kruskall-Wallis ANOVAs were performed, followed by post hoc non parametric paired comparison tests. A hierarchical clustering based on normalized Euclidean distance and Ward's criterion was performed on mean isotopic ratios to identify groups of plankton with similar isotopic ratios. The relationship between PCB concentration and $\delta^{15} \mathrm{~N}$ was tested on $\log -\log$ transformed data for all size classes and sampling dates to linearize the regression. The relationship between PCB concentration and biomass of plankton was tested to linearize regression.

\section{Results}

\subsection{Environmental and biogeochemical conditions}

Environmental meteorological data over a period of seven days before sampling of wind speed and direction, Huveaune River flow and total cumulative precipitation are summarized in Table 2. Mean wind conditions (average direction and intensity for seven days to prior sampling date) varied among sampling dates. The highest mean wind speed $\left(>11 \mathrm{~m} \mathrm{~s}^{-1}\right)$ occurred for the 16 th of November (sample S2), the 14th of December, 2010 (sample S3) 
Table 2

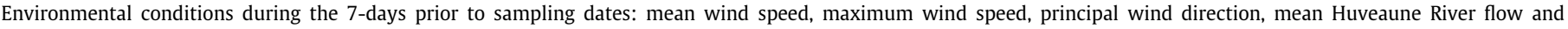
cumulative rainfall.

\begin{tabular}{|c|c|c|c|c|c|}
\hline Date & Mean wind speed $\left(\mathrm{m} \mathrm{s}^{-1}\right)$ & Max wind speed $\left(\mathrm{m} \mathrm{s}^{-1}\right)$ & Mean wind direction & Mean output of Huveaune $\left(\mathrm{m}^{3} \mathrm{~s}^{-1}\right)$ & Cumulative rainfall $(\mathrm{mm})$ \\
\hline S1 & 7.51 & 13.28 & SE & 0.84 & 17.2 \\
\hline S2 & 12.56 & 15.67 & NW & 0.76 & 7.6 \\
\hline S3 & 12.18 & 15.67 & NW & 1.02 & 0.0 \\
\hline S4 & 8.01 & 13.54 & NW & 1.07 & 1.8 \\
\hline S5 & 7.48 & 19.17 & $\mathrm{~S}$ & 1.62 & 0.2 \\
\hline S6 & 5.67 & 17.00 & SE & 2.79 & 96.2 \\
\hline S7 & 11.29 & 19.71 & NW & 0.24 & 0.0 \\
\hline
\end{tabular}

and the 11th of October, 2011 (sample S7) sampling dates with NW winds (mistral). On the $23^{\mathrm{d}}$ of January, 2011 (sample S4), the mistral occurred on only one day during the 7 days before sampling. The lowest values occurred for South-Eastern (samples S1 and S6) or South (sample S5) winds. High cumulative rainfall occurred when the SE wind blew in September, 2010 (S1) and June 2011 (S6) and was low at the other dates, excepted for the S2 sample. The Huveaune River flow peaked also in June 2011 as a result of high rain falls. The Huveaune river discharge was within the annual ranges, except for sample S6.

Chlorophyll $\boldsymbol{a}$ concentrations were low with a mean of $0.245 \mu \mathrm{g} \mathrm{l} \mathrm{l}^{-1} \pm 0.156$ (Fig. 2a). The highest values were observed for S5 (15th April, 2011: $0.556 \mu \mathrm{g} \mathrm{l}^{-1}$ ) and S6 (7th June, 2011: $0.370 \mu \mathrm{g} \mathrm{l}^{-1}$ ), and the lowest for S1 (8th September, 2010: $0.152 \mu \mathrm{g} \mathrm{l}^{-1}$ ), S2 (16th November, 2010: $0.110 \mu \mathrm{g} \mathrm{l}^{-1}$ ) and S4 (23th January, 2011: $\left.0.118 \mu \mathrm{g} \mathrm{l}^{-1}\right)$. The pigment ratio, chla/(chla + pheo), was generally high (0.60-0.75) except in S7 (0.47).

Plankton biomass (Fig. 2b) presented two peaks in S3 (15.89 $\mathrm{mg} \mathrm{m}^{-3}$ d.w.) and S5 (26.17 $\mathrm{mg} \mathrm{m}^{-3}$ d.w.) with an increase in biomass in all size plankton fractions. The $200-500 \mu \mathrm{m}$ size class

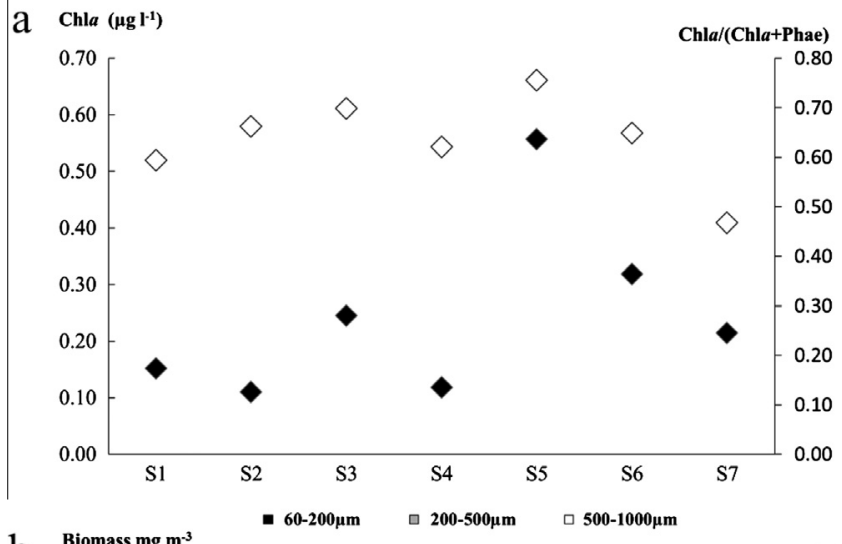

b

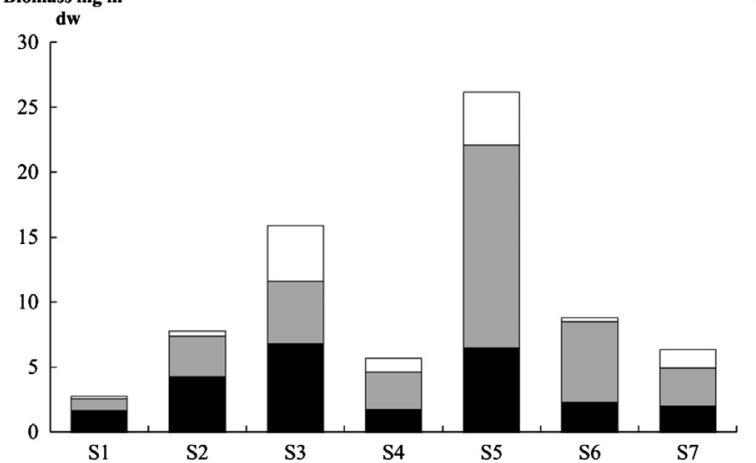

Fig. 2. (a) Concentration of chlorophyll $a$ (black) and pigment ratio (white) and (b) plankton biomass (dry weight, $\mathrm{mg} \mathrm{m}^{-3}$ ) of size classes: $60-200 \mu \mathrm{m}$ (black); 200$500 \mu \mathrm{m}$ (grey) and 500-1000 $\mu \mathrm{m}$ (white) in September, November and December 2010, and January, April, June and October 2011. was the main contributor for this spring biomass increase. The biomass concentration in the $500-1000 \mu \mathrm{m}$ fraction remained generally low $\left(0.20-1.45 \mathrm{mg} \mathrm{m}^{-3}\right)$, except in S3 and S5.

Composition in plankton categories varied with sampling dates, with differences between the two size classes (200-500 $\mu \mathrm{m}$ and $500-1000 \mu \mathrm{m})$ (Fig. 3). Both classes were dominated by two plankton categories: unidentified particles, further referred to as detritus (mostly crashed plankton), and copepods. Detritus represented $4-55 \%$ of the total biomass of the $200-500 \mu \mathrm{m}$ size fraction and $2-22 \%$ of the $500-1000 \mu \mathrm{m}$ size fraction. Copepods represented $41-95 \%$ and $63-97 \%$ of the biomass of the same size fractions respectively. In both fractions, the highest percentages of contribution to biomass for detritus and the lowest for copepods were recorded in samples from 2010. Among other plankton
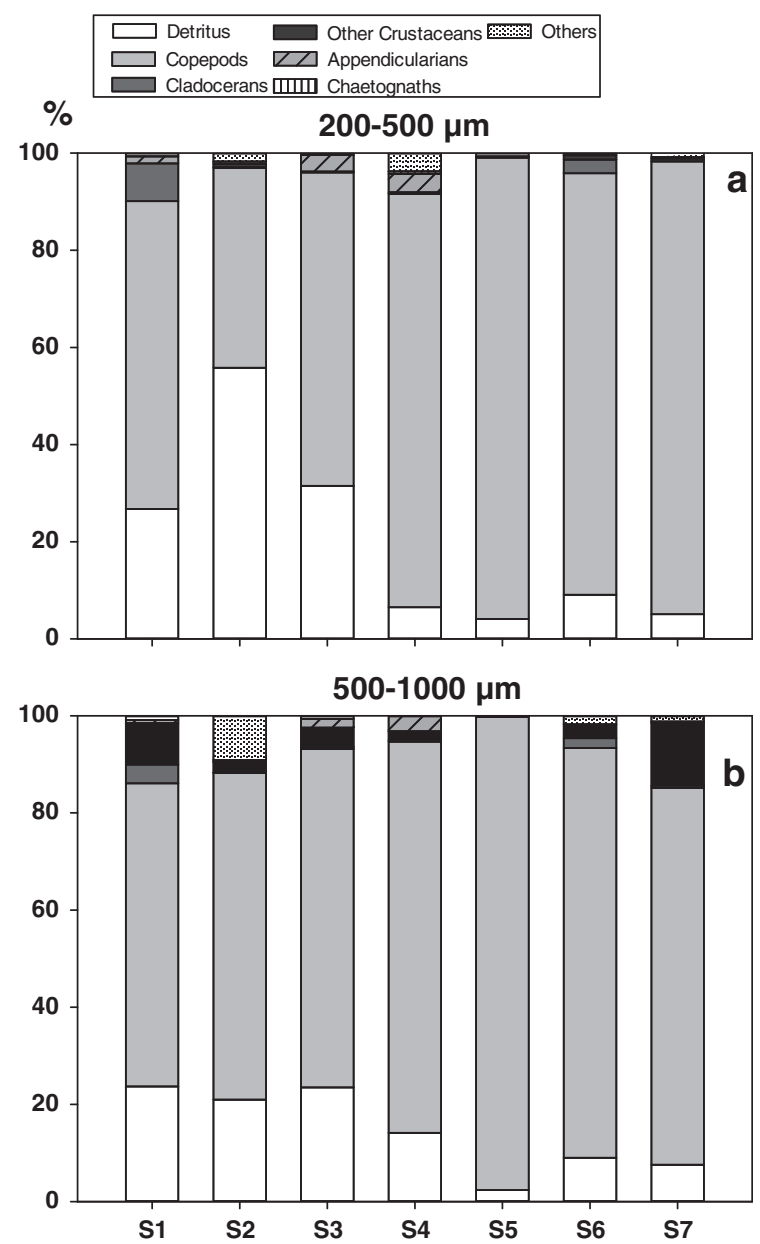

Fig. 3. Temporal variation of the composition in plankton categories (a) 200$500 \mu \mathrm{m}$ and (b) 500-1000 $\mu \mathrm{m}$ expressed in percentage of dry mass in September, November and December 2010, and January, April, June and October 2011. 
categories, "cladocerans" and "appendicularians" occurred in the 200-500 $\mu \mathrm{m}$ size fraction while "other crustaceans" (decapods and euphausids) were numerous in the $500-1000 \mu \mathrm{m}$ size fraction. In both fractions, non-copepod taxa and detritus were very low in S5. The size fraction 60-200 $\mu \mathrm{m}$ reflected the size overlap between phyto- and zooplankton. It contained, apart from phytoplankton, a substantial proportion of zooplankton. The proportion consisting strictly of diatoms and dinoflagellates in the 60-200 $\mu \mathrm{m}$ size fraction, varied between $16.8 \%$ (S3) and $94.3 \%$ (S2), with a mean of $55.4 \%$.

Carbon and nitrogen stable isotope signatures of plankton varied with size and season (Fig. 4). $\delta^{15} \mathrm{~N}$ ranged between $2.9 \%$ and $4.9 \%, 2.9 \%$ and $6.1 \%$, and $3.6 \%$ and $5.4 \%$ for the $60-200 \mu \mathrm{m}$, $200-500 \mu \mathrm{m}$ and $500-1000 \mu \mathrm{m}$ size classes respectively. $\delta^{13} \mathrm{C}$ ranged between $-23.3 \%$ and $-20.5 \%$, $-23.5 \%$ and $-20.3 \%$, and $-24.2 \%$ and $-19.8 \%$ for the $60-200 \mu \mathrm{m}, 200-500 \mu \mathrm{m}$ and $500-1000 \mu \mathrm{m}$ size classes respectively (Table 4). The average $\delta^{13} \mathrm{C}$ and $\delta^{15} \mathrm{~N}$ values, for all sampling periods combined, did not differ among size classes $\left(\delta^{13} \mathrm{C}: F=0.267, p=0.875, \quad \delta^{15} \mathrm{~N}\right.$ : $F=0.709, p=0.505$ ). The $\delta^{13} \mathrm{C}$ versus $\delta^{15} \mathrm{~N}$ plot (Fig. 4) and the hierarchical clustering enable us to distinguish three groups of isotopic signatures in planktonic size fractions. The first group, corresponding to the S1 and S4 samples, was characterized by low $\delta^{15} \mathrm{~N}$ (range $2.9-3.8 \%$ ) and intermediate $\delta^{13} \mathrm{C}$ values (range $-22.2 \%$ to $-21.2 \%$ ) (Table 4). The second group (S2, S3 and S7) was characterized by high values for both $\delta^{15} \mathrm{~N}$ (range $4.3-5.4 \%$ ) and $\delta^{13} \mathrm{C}$ (range $-21.2 \%$ to $-19.8 \%$ ). The third group (S5 and S6) was characterized by low $\delta^{13} \mathrm{C}$ signatures (range $-24.2 \%$ to $-23.3 \%$ ) and variable $\delta^{15} \mathrm{~N}$ (range $3.4-8.7 \%$ ). The increase in $\delta^{15} \mathrm{~N}$ with plankton size was observed only at certain periods (S2, S3, S5 and S7), and was generally coupled with a very slight increase of $\delta^{13} \mathrm{C}$, except in S5. In other periods, no clear variation of isotopic ratios with size classes was observed (see Fig. 4).

\subsection{PCB concentrations in plankton size classes}

The total $\sum \mathrm{PCB}_{7}$ concentration ranged from 14.2 to $88.1 \mathrm{ng} \mathrm{g}^{-1}$ d.w., for all size classes and all sampling periods (Table 4). CB28 and CB153 concentrations ranged from between 0.1 and $1.2 \mathrm{ng} \mathrm{g}^{-1} \mathrm{~d} . \mathrm{w}$. and 5.5 and $29.1 \mathrm{ng} \mathrm{g}^{-1} \mathrm{~d} . \mathrm{w}$. respectively. The highest mean PCB concentration was observed in S7, and the lowest in S4 and S5. Mean annual concentrations did not differ significantly among size classes $\left(\sum \mathrm{PCB}_{7}, F=0.167, p=0.847 ; \mathrm{CB} 28\right.$, $F=0.55, p=0.58$; CB153, $F=1.34, p=0.28$ ). However, a strong variation with time was observed in each size class (Table 4) and there was no systematic trend among increasing size classes (Fig. 5). The highest values for $\sum \mathrm{PCB}_{7}$ of the $60-200 \mu \mathrm{m}$ size class were observed in S3 and S7and the lowest in S4, S5 andS6. The concentrations of PCB were generally lower in the 200-500 $\mu \mathrm{m}$ fraction, but were also higher in S3 and S7, when compared to other periods. A slightly different pattern of PCB concentrations was observed in the larger plankton 500-1000 $\mu \mathrm{m}$ size class, with the higher levels observed in S2, S6, and especially in S7.

A significant linear regression was observed between $\sum \mathrm{PCB}_{7}$ concentration and $\delta^{15} \mathrm{~N} \quad\left(\log _{\Sigma \mathrm{PCB} 7}=0.727 \quad \log \delta_{15 \mathrm{~N}}+1.028\right.$,
$R^{2}=0.22, p=0.03, N=21$ ). This relation was slightly higher when the two larger plankton size classes were only taken into account $\left(R^{2}=0.39, p=0.01, N=14\right)$.

The total mean percentage of organic solvent extractable lipids was low in the analyzed plankton fractions $(2.97 \pm 2.79 \%)$ and did not differ significantly with size $(F=0.48, p=0.625)$ or sampling date $(F=1.577, p=0.226)$. Lipid content was not correlated with PCB concentration neither for all size classes combined $\left(R^{2}<0.001, p=0.952\right)$, nor for each size class $(p>0.05)$.

\section{Discussion}

\subsection{Plankton biomass and $P C B$ concentration}

We have examined PCB concentrations versus plankton biomasses in the water of the Bay of Marseille. No correlation was observed between plankton biomass and PCB concentrations, regardless of the congeners (or summed concentration of $\sum \mathrm{PCB}_{7}$ ) and size classes considered. These results diverge from the "biomass dilution effect" process, which implies the decrease of PCB concentration in plankton with increasing planktonic biomass (Taylor et al., 1991; Frouin et al., 2013; Konat-Stepowicz and Kowalewska, 2003). Indeed, fast plankton growth and a larger biomass present in the system may reduce the water concentration of PCBs and consequently may lead to their lower concentration per mass unit of plankton (Niimi and Cho, 1981; Axelman et al., 1997). Such a trend should thus be observed for all compounds, regardless of their physicochemical properties (Berrojalbiz et al., 2011). Furthermore, the "biomass dilution effect" implies low inputs and losses of PCBs in the system and fast plankton growth (Berrojalbiz et al., 2011). However, coastal areas, such as those in the Bay of Marseille, are characterized by variable inputs of chemicals. In these ecosystems PCB levels in plankton may be strongly influenced by external loads (river and sewage discharges) and sediment resuspension. Such contaminants inputs in the coastal shallow waters may be confounding factors, masking a relationship between plankton biomass and PCB concentrations in plankton.

The absence of an apparent dilution effect in the Bay of Marseille is also consistent with the lack of the relationship found between Chl $a$ (proxy of phytoplankton biomass) and PCB concentrations in plankton. The uptake by phytoplankton is, indeed the main pathway entry for PCBs into marine food webs (Dachs et al., 1999). It has also been suggested that higher phytoplankton biomasses and associated settling fluxes will ultimately lower the PCB concentrations in the marine environment (Dachs et al., 2002). The lack of the chla-PCB relationship in our study may be linked to the fact that in field studies, the separation of the pure phytoplankton fraction for trace level contaminant analysis is difficult. Furthermore, many detritic planktonic cells may be collected with the phytoplankton. In our set of plankton samples the chla/(chla+ pheo) ratio, generally higher than 0.6 , except in S7(Fig. 2), indicated however freshly produced phytoplankton (Plante-Cuny and Bodoy, 1987). On the other hand, low concentration of PCBs in

Table 3

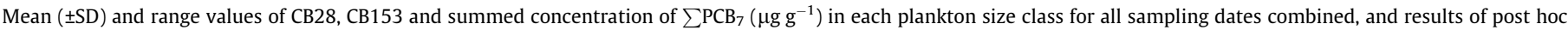
tests. Different letters indicate significantly different means.

\begin{tabular}{|c|c|c|c|c|c|}
\hline Size classes & $\delta^{13} \mathrm{C}(\% o)$ & $\delta^{15} \mathrm{~N}(\% 0)$ & CB $28\left(\right.$ ng g $\left.^{-1}\right)$ & CB $153\left(\mathrm{ng} \mathrm{g}^{-1}\right)$ & $\sum \mathrm{PCB}_{7}\left(\mathrm{ng} \mathrm{g}^{-1}\right)$ \\
\hline $60-200 \mu \mathrm{m}$ & $\begin{array}{l}-21.7 \pm 0.9^{\mathrm{a}} \\
(-23.3 ;-20.5)\end{array}$ & $\begin{array}{l}3.9 \pm 0.8^{\mathrm{a}} \\
(2.9 ; 4.9)\end{array}$ & $\begin{array}{l}0.5 \pm 0.3^{\mathrm{a}} \\
(0.3 ; 1.0)\end{array}$ & $\begin{array}{l}13.8 \pm 8.5^{\mathrm{a}} \\
(5.5 ; 29.1)\end{array}$ & $\begin{array}{l}38.5 \pm 25.8^{a} \\
(15.1 ; 88.1)\end{array}$ \\
\hline $200-500 \mu \mathrm{m}$ & $\begin{array}{l}-21.9 \pm 1.2^{\mathrm{a}} \\
(-23.5 ;-20.5)\end{array}$ & $\begin{array}{l}4.2 \pm 1.2^{\mathrm{a}} \\
(2.9 ; 6.1)\end{array}$ & $\begin{array}{l}0.3 \pm 0.1^{a} \\
(0.1 ; 0.4)\end{array}$ & $\begin{array}{l}10.4 \pm 3.1^{\mathrm{a}} \\
(5.9 ; 14.4)\end{array}$ & $\begin{array}{l}26.8 \pm 9.2^{\mathrm{a}} \\
(14.7 ; 38.8)\end{array}$ \\
\hline $500-1000 \mu \mathrm{m}$ & $\begin{array}{l}-21.9 \pm 1.5^{\mathrm{a}} \\
(-24.2 ;-19.8)\end{array}$ & $\begin{array}{l}4.5 \pm 1.5^{\mathrm{a}} \\
(3.6 ; 5.4)\end{array}$ & $\begin{array}{l}0.4 \pm 0.4^{\mathrm{a}} \\
(0.1 ; 1.2)\end{array}$ & $\begin{array}{l}12.9 \pm 6.1^{\mathrm{a}} \\
(5.7 ; 22.9)\end{array}$ & $\begin{array}{l}33.0 \pm 18.8^{a} \\
(14.2 ; 69.4)\end{array}$ \\
\hline
\end{tabular}


Table 4

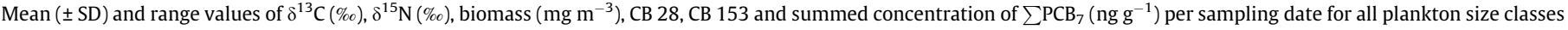
combined, and results of post hoc tests. Different letters indicate significantly different means.

\begin{tabular}{|c|c|c|c|c|c|c|}
\hline Date & $\delta^{13} \mathrm{C}(\% o)$ & $\delta^{15} \mathrm{~N}(\% 0)$ & Biomass $\left(\mathrm{mg} \mathrm{m}^{-3}\right)$ & CB $28\left(\right.$ ng g $\left.^{-1}\right)$ & CB $153\left(\mathrm{ng} \mathrm{g}^{-1}\right)$ & $\sum \mathrm{PCB}_{7}\left(\mathrm{ng} \mathrm{g}^{-1}\right)$ \\
\hline \multirow[t]{2}{*}{ S1 } & $-21.8 \pm 0.3^{\mathrm{ab}}$ & $3.4 \pm 0.3^{\mathrm{ab}}$ & $0.70 \pm 0.74^{\mathrm{a}}$ & $0.5 \pm 0.2 \mathrm{ab}$ & $10.4 \pm 0.9^{\mathrm{ab}}$ & $25.0 \pm 3.80^{\mathrm{a}}$ \\
\hline & $(-21.9 ;-21.2)$ & $(3.1 ; 3.7)$ & $(1.65 ; 0.04)$ & $(0.3 ; 0.7)$ & $(9.5 ; 11.1)$ & $(21.5 ; 29.0)$ \\
\hline \multirow[t]{2}{*}{ S2 } & $-20.9 \pm 0.2^{\mathrm{ab}}$ & $4.5 \pm 0.6^{\mathrm{bc}}$ & $1.97 \pm 2.05^{\mathrm{a}}$ & $0.5 \pm 0.2^{\mathrm{ab}}$ & $13.7 \pm 2.2^{\mathrm{ab}}$ & $35.4 \pm 5.2^{\mathrm{ab}}$ \\
\hline & $(-21.8 ;-20.7)$ & $(4.3 ; 5.2)$ & $(4.24 ; 0.07)$ & $(0.3 ; 0.7)$ & $(11.7 ; 16.1)$ & $(29.6 ; 39.8)$ \\
\hline \multirow[t]{2}{*}{ S3 } & $-20.2 \pm 0.4^{\mathrm{b}}$ & $4.9 \pm 0.3^{\mathrm{bc}}$ & $4.06 \pm 2.69^{\mathrm{a}}$ & $0.4 \pm 0.2^{\mathrm{ab}}$ & $14.4 \pm 6.9^{\mathrm{ab}}$ & $38.1 \pm 19.2^{\mathrm{ab}}$ \\
\hline & $(-20.5 ;-19.8)$ & $(4.6 ; 5.3)$ & $(6.79 ; 0.36)$ & $(0.2 ; 0.6)$ & $(7.7 ; 21.5)$ & $(18.4 ; 56.9)$ \\
\hline \multirow[t]{2}{*}{ S4 } & $-22.0 \pm 0.2^{\mathrm{ab}}$ & $3.1 \pm 0.4^{\mathrm{a}}$ & $1.50 \pm 1.09^{a}$ & $0.2 \pm 0.1^{\mathrm{a}}$ & $7.0 \pm 2.1^{\mathrm{a}}$ & $17.1 \pm 4.6^{\mathrm{a}}$ \\
\hline & $(-22.2 ;-21.8)$ & $(2.9 ; 3.6)$ & $(2.88 ; 0.32)$ & $(0.1 ; 0.3)$ & $(5.7 ; 9.5)$ & $(14.2 ; 22.4)$ \\
\hline \multirow[t]{2}{*}{ S5 } & $-23.0 \pm 0.7^{\mathrm{a}}$ & $3.4 \pm 0.3^{\mathrm{a}}$ & $6.68 \pm 6.44^{\mathrm{a}}$ & $0.2 \pm 0.1^{\mathrm{a}}$ & $8.1 \pm 2.3^{\mathrm{a}}$ & $20.6 \pm 4.9^{\mathrm{a}}$ \\
\hline & $(-23.5 ;-23.0)$ & $(3.4 ; 3.7)$ & $(15.62 ; 0.54)$ & $(0.2 ; 0.3)$ & $(5.5 ; 9.6)$ & $(15.1 ; 24.6)$ \\
\hline \multirow[t]{2}{*}{ S6 } & $-23.7 \pm 0.4^{\mathrm{a}}$ & $5.1 \pm 0.8^{c}$ & $2.22 \pm 2.83^{\mathrm{a}}$ & $0.3 \pm 0.1^{\mathrm{ab}}$ & $10.5 \pm 5.5^{\mathrm{ab}}$ & $27.8 \pm 10.6^{\mathrm{a}}$ \\
\hline & $(-24.2 ;-23.3)$ & $(4.4 ; 6.1)$ & $(6.20 ; 0.11)$ & $(0.2 ; 0.4)$ & $(7.2 ; 17.2)$ & $(21.1 ; 39.9)$ \\
\hline \multirow[t]{2}{*}{ S7 } & $-21.5 \pm 0.1^{\mathrm{ab}}$ & $5.0 \pm 0.3^{\mathrm{bc}}$ & $1.62 \pm 1.17^{a}$ & $0.9 \pm 0.4^{b}$ & $22.1 \pm 7.4^{b}$ & $65.4 \pm 25.0^{b}$ \\
\hline & $(-21.2 ;-24.4)$ & $(4.7 ; 5.4)$ & $(2.92 ; 0.11)$ & $(0.4 ; 1.2)$ & $(14.4 ; 29.1)$ & $(38.6 ; 88.1)$ \\
\hline
\end{tabular}

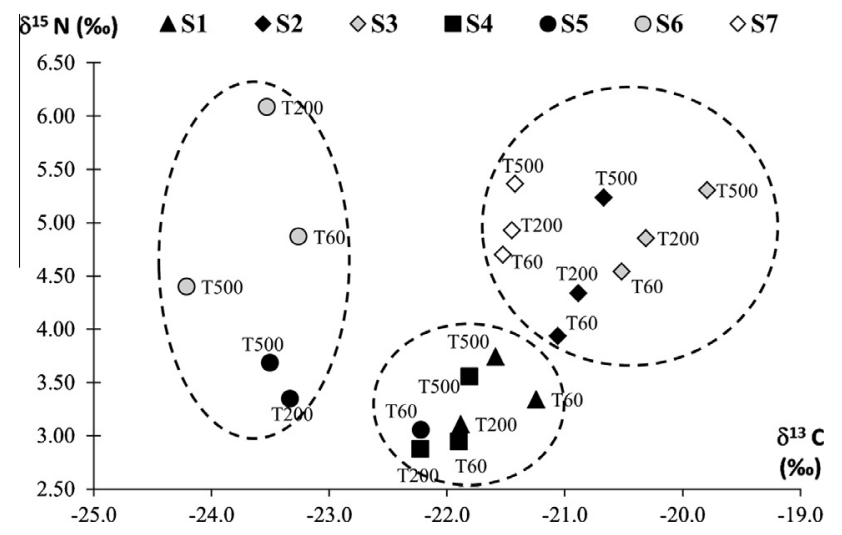

Fig. 4. Temporal variation of $\delta^{13} \mathrm{C}$ and $\delta^{15} \mathrm{~N}(\%)$ of the different size fractions of plankton $(60-200 \mu \mathrm{m}=\mathrm{T} 60,200-500 \mu \mathrm{m}=\mathrm{T} 200$ and $500-1000 \mu \mathrm{m}=\mathrm{T} 500)$ in September (black triangles), November (black diamonds), and December 2010 (grey diamonds), and January (black squares), April (black circles), June (grey circles) and October 2011 (white diamond). The dash circle identifies three different clusters based on normalized Euclidean distance and Ward's criterion.

plankton was observed in spring (S5) that is after the spring bloom, which corresponded to the maximum in Chl $a$ concentration and higher plankton biomass. Furthermore, in spite of calmer weather conditions in spring, intense wind events were observed, resulting in a regular sediment resuspension also during this period (Vousdoukas et al., 2011). We may thus suppose that the low PCB concentration observed in spring could be, nevertheless, related to the biological pump processes at that time, as observed elsewhere (Nizzetto et al., 2012).

\section{2. $P C B$ concentration versus size class, isotopic signature and taxonomy of plankton}

A number of studies have shown the trophic transfer of persistent organic contaminants along marine food webs (Harding et al., 1997; Berglund et al., 2000; Borgå et al., 2004; Magnusson et al., 2007). The biomagnification process implies that contaminant concentration increases with the increasing trophic level in the marine food-web (Byun et al., 2013). However, prey-predator contaminant transfer appears to be difficult to distinguish clearly within planktonic food-webs, especially in field studies (Sobek et al., 2006; Hallanger et al., 2011). In field samples, size class and isotope signatures do not necessarily reflect a prey-predator relationships, and complex ecology and ecosystem interactions within plankton communities (Sobek et al., 2006; Hallanger et al., 2011). Thus, evidencing and quantifying contaminant biomagnification in plankton is a difficult task. We have determined the nitrogen isotope signature in different plankton size classes of the Bay of Marseille. In this set of samples the relationship between PCB concentrations, the size of plankton and $\delta^{15} \mathrm{~N}$ signatures is not straightforward. Actually, the PCB concentrations in the Bay of Marseille were not size related. Generally higher concentrations were determined in the lowest $60-200 \mu \mathrm{m}$ size class (mean $38.5 \pm 25.8 \mathrm{ng} \mathrm{g}^{-1}$ d.w., Table 3). However, the mean PCB concentration was higher in the $500-1000 \mu \mathrm{m}$ size class than in the $200-500 \mu \mathrm{m}$ size class (33.0 $\pm 18.8 \mathrm{ng} \mathrm{g}^{-1}$ and $26.8 \pm 9.2 \mathrm{ng} \mathrm{g}^{-1}$ respectively). These means were not statistically different, probably due to high seasonal variations in our data set. The higher PCB concentration determined in the lowest size class of plankton might be related to the passive diffusive partition uptake of contaminants in this size fraction, while larger plankton size classes are composed of organisms with different diets, including herbivores, carnivores and detritivores, susceptible, in addition, to adapt their diet to the quantity of available resources (Saiz et al., 2007; Banaru et al., 2013). Consequently, the biomagnification of PCBs over the range of plankton size classes was frequently not observed in field studies (Berglund et al. 2000; Harding et al., 1997).

On the other hand, in the plankton samples collected in the Bay of Marseille, a moderate but significant positive relationship $\left(R^{2}=0.22, p=0.03\right)$ between $\mathrm{PCB}$ concentration and $\delta^{15} \mathrm{~N}$ was observed. This correlation was even slightly higher in the larger zooplankton size range $\left(200-1000 \mu \mathrm{m} ; R^{2}=0.39, p=0.01\right)$. However, for this data set, the range of $\delta^{15} \mathrm{~N}$ signatures in plankton is very narrow. The best fitted curve between CB153 concentration and $\delta^{15} \mathrm{~N}$ data (not log transformed) was a power curve $\left(y=1.129 \mathrm{x}^{1.556}, R^{2}=0.23\right)$. But the slope of this power curve for the plankton food web (1.556) is very low in comparison with the one found by Harmelin-Vivien et al. (2012) for the hake food web in the GoL (2.84), corroborating the results that PCB biomagnification is low in plankton.

The diets of planktonic organisms can explain the expected $\delta^{15} \mathrm{~N}$ enrichment in zooplankton (Rolff, 2000). Carnivores (chaetognaths, large crustaceans) present the highest $\delta^{15} \mathrm{~N}$ values, while filter feeders (numerous copepods, ostracods, appendicularians) show lower signatures (Mcconnaughey and Mcroy, 1979; Fanelli et al., 2011). Consequently, high $\delta^{15} \mathrm{~N}$ values should presented a higher PCB level than low $\delta^{15} \mathrm{~N}$ values, in accordance with biomagnification. During our survey, the $\delta^{15} \mathrm{~N}$ enrichment between the $200-500 \mu \mathrm{m}$ and the $500-1000 \mu \mathrm{m}$ fractions was systematically detected (except in S6). This is in accordance with the classical taxonomic composition of these fractions, which presents an increase in biomass of noncopepod crustaceans and chaetognaths (carnivores) and a decrease of cladocerans and appendicularians (filter feeders). However, this $\delta^{15} \mathrm{~N}$ enrichment was not necessarily related to an increase of PCB 


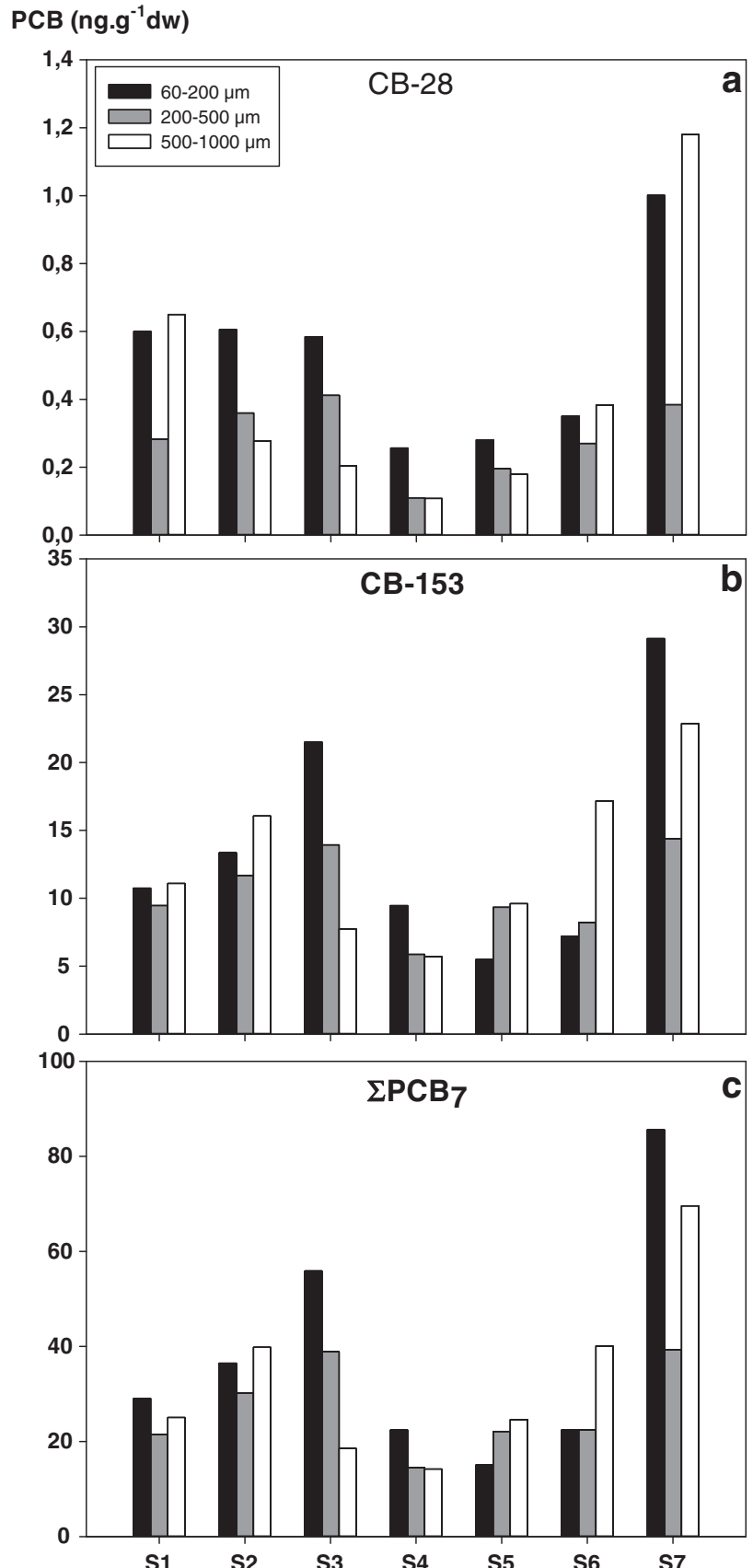

Fig. 5. Concentration (ng g ${ }^{-1}$ dry weight) of (a) $\mathrm{CB} 28$, (b) $\mathrm{CB} 153$ and (c) $\sum \mathrm{PCB}_{7}$ (CB28, CB52, CB101, CB118, CB138, CB153, CB180) in the different plankton size classes: $60-200 \mu \mathrm{m}$ (black), $200-500 \mu \mathrm{m}$ (grey) and $500-1000 \mu \mathrm{m}$ (white) in September, November, and December 2010, and January, April, June and October 2011.

concentration (S3, S4 for $\sum \mathrm{PCB}_{7}$ and $\mathrm{CB} 153$; S2, S3, S4 and S5 for CB28). Interestingly, in $\mathrm{S} 6$ we still observed an increase of other crustaceans, which was not supported by the concomitant $\delta{ }^{15} \mathrm{~N}$ decrease in the $500-1000 \mu \mathrm{m}$ fraction.

\subsection{Possible role of sediment resuspension and continental inputs}

In the Bay of Marseille strong mistral winds were registered, with a mean speed exceeding $10 \mathrm{~ms}^{-1}$ over seven days before sampling in S2, S3, and S7 (Table 2). These conditions generate a current flowing in a north-south direction in the bay, driving waters from the harbor area to the sampling station (Castelbon, 1972). In these sampling periods, the plankton presented a narrow range of $\delta^{13} \mathrm{C}$ and $\delta^{15} \mathrm{~N}$ isotopic signatures, and high PCB concentrations, particularly in the $60-200 \mu \mathrm{m}$ size class. These results suggest that plankton characteristics and contamination by PCB may perhaps have been affected by the hydrodynamics induced by the wind. The significant amounts of resuspended superficial sediments in the relatively shallow Bay of Marseille were reported previously, as predicted by 3D models (Vousdoukas et al., 2011; Pinazo et al., 2013). The sediments and filtering marine mollusks in Marseille Bay are strongly contaminated by PCB (Sauzade et al., 2009). During strong mistral winds we have found that CB153 concentration significantly increased in the $60-200 \mu \mathrm{m}$ fraction (from $6.159 \pm 3.971 \mathrm{ng} \mathrm{g}^{-1} \mathrm{~d} . \mathrm{w}$. during $\mathrm{E}$ or $\mathrm{SE}$ winds, to $21.334 \pm 7.897 \mathrm{ng} \mathrm{g}^{-1}$ during NW winds; $F=11.473, p=0.019$ ). Thus, we may suppose that the higher contamination mainly of phytoplankton by PCBs during high wind period was most likely related to the resuspension of contaminated sediments like detritus derived from plankton and the release of pore water contaminants (Konat-Stepowicz and Kowalewska, 2003). Similar results, i.e. higher concentrations of PCBs during resuspension events, were also described in the Great Lakes (Martinez et al., 2010) and in other places (Ko and Beker, 1995; Dachs and Méjanelle, 2010). Furthermore, in the Bay of Marseille biomagnification factors (BMFs), calculated for instance for $\mathrm{CB} 153$ congener, as the ratio of the 200-1000 $\mu \mathrm{m}$ concentration over the $60-200 \mu \mathrm{m}$ concentration, were not related to plankton biomass $\left(R^{2}=0.26, p=0.236\right)$ and the highest BMF was found when the biomass was high (S5). These results differ from those of Nizzetto et al. (2012), who demonstrate a decrease of BMF during and after the phytoplankton bloom mainly due to an increase in zooplankton biomass. The different trend in the Bay of Marseille may be again related to important sediment resuspension after strong wind events that induced lack of apparent BMFs to plankton biomass relationship.

At S6 the higher level of PCBs was determined only in the $500-1000 \mu \mathrm{m}$ plankton fraction, concomitant with a high rainy event (Table 2), low $\delta^{13} \mathrm{C}$ and high $\delta^{15} \mathrm{~N}$ plankton isotopic signatures (Fig. 3). These stable isotopic signatures were similar to those of coastal particulate organic matter influenced by the freshwater discharges of the Huveaune River (Cresson et al., 2012). During the seven days before sampling (S6) the high Huveaune River flow was coupled with high rain falls, flushing out terrestrial matter to the sea (the plume was observed during sampling). The recent modeling study of the Huveaune River plume shows spatial dispersion of particulate PCB in the Bay of Marseille far enough to reach our sampling site (Jany et al., 2012; Fraysse et al., 2013). Furthermore, Banaru et al. (2013) have shown that terrestrial organic matter is incorporated into planktonic trophic webs at our study site.

Finally, in S1, S4 and S5, the isotopic signatures of plankton fractions were closer to those of the offshore POM (Darnaude et al., 2004). At these dates, PCB concentrations and $\delta^{15} \mathrm{~N}$ values were low, suggesting the presence of offshore waters, less impacted by contaminants at the sampling site (Cresson et al., 2012; Banaru et al., 2013). Thus, the alternation of contaminated coastal waters and less contaminated offshore waters in the Bay of Marseille, related to meteorological and hydrodynamic conditions, may have induced the observed variability of PCB concentrations in the plankton of the bay. These results, in the Bay of Marseille, suggest that a relationship between PCB concentrations in plankton and plankton biomass is unlikely to be observed in shallow coastal waters of the Bay.

\section{Conclusion}

Our study was aimed at understanding the PCB accumulation in the different size classes of plankton in the Bay of Marseilles. The results do not show the apparent biomass dilution effect and 
indicate moderate but significant biomagnification with plankton trophic position estimated by $\delta^{15} \mathrm{~N}$ signatures. This partly outcomes from the difficulty of clearly identifying the trophic relationship between plankton size classes, due to the presence of detritus (smaller size classes) and the mixing of different trophic levels within each size class. Our results also suggest the importance of wind events and continental inputs in increasing the concentration of PCB rich detritus in the water column and the PCB levels in plankton. Finally, our results showed that partition processes play an important role in PCB uptake by all plankton fractions in the Bay of Marseille.

\section{Acknowledgements}

We wish to express our thanks to the crew of the R.V. Antedon II and N/O Europe and to the colleagues who helped in sampling and to Patrick Raimbault in charge of the SOMLIT long-term survey in Marseille. Stable isotope analyses were performed at the University of La Rochelle (UMR LIENSs). This work is part of the COSTAS program (Contaminants dans le système trophique: phytoplancton, zooplancton, anchois, sardine ANR- AA-PPPP-007). M.T. benefited from a PhD grant funded by IFREMER and the region of PACA (France). The COSTAS project received also a financial support from ONEMA (Office national de l'eau et des milieu aquatiques) and from AE-RMC (Agence de l'eau Rhône, Méditerranée, Corse). We also thank the anonymous reviewer for his comments and suggestions that helped to improve this manuscript.

\section{References}

Aguilar, A., Borrell, A., 2005. DDT and PCB reduction in the western Mediterranean from 1987 to 2002, as shown by levels in striped dolphins (Stenella coeruleoalba). Mar. Environ. Res. 59, 391-404.

Aldebert, Y., Recasens, L., Lleonart, J., 1993. Analysis of gear interactions in a hake fishery: the case of the Gulf of Lions (NW Mediterranean). Sci. Mar. 57, $207-$ 217.

Aminot, A., Kerouel, R., 2004. Hydrologie des écosystèmes marins. Paramètres et analyses. Edition Ifremer, 336pp.

Axelman, J., Broman, D., Naf, C., 1997. Field measurements of PCB partitioning between water and planktonic organisms: influence of growth, particle size, and solute-solvent interactions. Environ. Sci. Technol. 31, 665-669.

Banaru, D., Carlotti, F., Barani, A., Grégori, G., Neffati, N., Harmelin-Vivien, M., 2013. Seasonal variation of stable isotope ratios of size-fractionated zooplankton in the Bay of Marseille (NW Mediterranean). J. Plankton Res., 1-12.

Barron, M.G., Heintz, R., Krahn, M.M., 2003. Contaminant exposure and effects in pinnipeds: implications for Steller sea lion declines in Alaska. Sci. Total Environ. 311, 111-133.

Berglund, O., Larsson, P., Ewald, G., Okla, L., 2000. Bioaccumulation and differential partitioning of polychlorinated biphenyls in freshwater, planktonic food webs. Can. J. Fish. Aquat. Sci. 57, 1160-1168.

Berrojalbiz, N., Dachs, J., Del Vento, S., Ojeda, M.J., Valle, M.C., Castro-Jimenez, J., Mariani, G., Wollgast, J., Hanke, G., 2011. Persistent organic pollutants in Mediterranean seawater and processes affecting their accumulation in Plankton. Environ. Sci. Technol. 45, 4315-4322.

Bodiguel, X., Tronczyński, J., Loizeau, V., Munschy, C., Guiot, N., Le Guellec, A.M., Olivier, N., Roupsard, F., Mellon, C., 2008. Classical and novel organohalogen compounds (PCBs and PBDEs) in hake (M. merluccius, L.) from Mediterranean and Atlantic coasts (France). Environmental Toxicology conference book (Wessex Institute of technology Transactions on Ecology and the environment, ISSN:1743-3541).

Bodiguel, X., Maury, O., Mellon-Duval, C., Roupsard, F., Le Guellec, A.M., Loizeau, V., 2009. A dynamic and mechanistic model of PCB bioaccumulation in the European hake (M. merluccius). J. Sea Res. 62, 124-134.

Binelli, A., Provini, A., 2003. The PCB pollution of Lake Iseo (N. Italy) and the role of biomagnification in the pelagic food web. Chemosphere 53 (2), 143-151.

Borgå, K., Fisk, A.T., Hoekstra, P.F., Muir, D.C.G., 2004. Biological and chemical factors of importance in the bioaccumulation and trophic transfer of persistent organochlorine contaminants in arctic marine food webs. Environ. Toxicol. Chem. 23, 2367-2385.

Burreau, S., Zebuhr, Y., Broman, D., Ishaq, R., 2006. Biomagnification of PBDEs and PCBs in food webs from the Baltic Sea and the northern Atlantic Ocean. Sci. Total. Environ. 366, 659-672.

Byun, G.H., Moon, H.B., Choi, J.H., Hwang, J., Kang, C.K., 2013. Biomagnification of persistent chlorinated and brominated contaminants in food web components of the Yellow Sea. Mar. Pollut. Bull. 73, 210-219.

Castelbon, C., 1972. Etude de la circulation des masses d'eau dans le golfe de Marseille. Téthys 4, 269-312.
Catalan, J., Ventura, M., Vives, I., Grimalt, J.O., 2004. The roles of food and water in the bioaccumulation of organochlorine compounds in high mountain lake fish. Environ. Sci. Technol. 38, 4269-4275.

Cresson, P., Ruitton, S., Fontaine, M.F., Harmelin-Vivien, M., 2012. Spatio-temporal variation of suspended and sedimentary organic matter quality on artificial reefs in Marseilles (NW Mediterranean) assessed by biochemical and isotopic analyses. Mar. Pollut. Bull. 64, 1112-1121.

Dachs, J., Méjanelle, L., 2010. Organic pollutants in coastal waters, sediments, and biota: a relevant driver for ecosystems during the Anthropocene? Estuar. Coasts 33, 1-14.

Dachs, J., Eisenreich, S.J., Baker, J.E., Ko, F.C., Jeremiason, J.D., 1999. Coupling of phytoplankton uptake and air-water exchange of persistent organic pollutants. Environ. Sci. Technol. 33, 3653-3660.

Dachs, J., Lohmann, R., Ockenden, W.A., Mejanelle, L., Eisenreich, S.J., Jones, K.C., 2002. Oceanic biogeochemical controls on global dynamics of persistent organic pollutants. Environ. Sci. Technol. 36, 4229-4237.

Darnaude, A.M., Salen-Picard, C., Polunin, N.V.C., Harmelin-Vivien, M.L., 2004 Trophodynamic linkage between river runoff and coastal fishery yield elucidated by stable isotope data in the Gulf of Lions (NW Mediterranean). Oecologia 138, 325-332.

Deniro, M.J., Epstein, S., 1978. Influence of diet on distribution of carbon isotopes in animals. Geochim. Cosmochim. Acta 42, 495-506.

Durrieu de Madron, X., Guieu, C., Sempéré, R., Conan, P., Cossa, D., D’Ortenzio, F. Verney, R., 2011. Review: marine ecosystems' responses to climatic and anthropogenic forcings in the Mediterranean. Progr. Oceanogr. 91 (2011), 97 166.

Elliott, K.H., Cesh, L.S., Dooley, J.A., Letcher, R.J., Elliott, J.E., 2009. PCBs and DDE, but not PBDEs, increase with trophic level and marine input in nestling bald eagles. Sci. Total Environ. 407, 3867-3875.

Fanelli, E., Cartes, J.E., Papiol, V., 2011. Food web structure of deep-sea macrozooplankton and micronekton off the Catalan slope: insight from stable isotopes. J. Mar. Syst. 87, 79-89.

Fisk, A.T., Hobson, K.A., Norstrom, R.J., 2001. Influence of chemical and biological factors on trophic transfer of persistent organic pollutants in the northwater polynya marine food web. Environ. Sci. Technol. 35, 732-738.

Fraysse, M., Pinazo, C., Faure, V.M., Fuchs, R., Lazzari, P., Raimbault, P., Pairaud, I., 2013. Development of a 3D coupled physical-biogeochemical model for the Marseille coastal area (NW Mediterranean Sea): What complexity is required in the coastal zone? PloS ONE 8 (12), e80012. http://dx.doi.org/10.1371/ journal.pone.0080012.

Frouin, H., Dangerfield, N., Macdonald, R.W., Galbraith, M., Crewe, N., Shaw, P. Mackas, D., Ross, P.S., 2013. Partitioning and bioaccumulation of PCBs and PBDEs in marine plankton from the Strait of Georgia, British Columbia, Canada. Progr. Oceanogr. 115, 65-75.

Gomez-Gutierrez, A., Garnacho, E., Bayona, J.M., Albaiges, J., 2007. Screening ecological risk assessment of persistent organic pollutants in Mediterranean sea sediments. Environ. Int. 33, 867-876.

Gregori, G., Colosimo, A., Denis, M., 2001. Phytoplankton group dynamics in the Bay of Marseilles during a 2-year survey based on analytical flow cytometry. Cytometry 44, 247-256.

Grosjean, P., Picheral, M., Warembourg, C., Gorsky, G., 2004. Enumeration, measurement, and identification of net zooplankton samples using the ZOOSCAN digital imaging system. ICES J. Mar. Sci. 61, 518-525.

Hallanger, I.G., Warner, N.A., Ruus, A., Evenset, A., Christensen, G., Herzke, D. Gabrielsen, G.W., Borgå, K., 2011. Seasonality in contaminant accumulation in Arctic marine pelagic food webs using trophic magnification factor as a measure of bioaccumulation. Environ. Toxicol. Chem. 30, 1026-1035.

Harding, G.C., LeBlanc, R.J., Vass, W.P., Addison, R.F., Hargrave, B.T., Pearre, S. Dupuis, A., Brodie, P.F., 1997. Bioaccumulation of polychlorinated biphenyls (PCBs) in the marine pelagic food web, based on a seasonal study in the southern Gulf of St. Lawrence, 1976-1977. Mar. Chem. 56, 145-179.

Harmelin-Vivien, M., Bodiguel, X., Charmasson, S., Loizeau, V., Mellon-Duval, C., Tronczynski, J., Cossa, D., 2012. Differential biomagnification of PCB, PBDE, Hg and Radiocesium in the food web of the European hake from the NW Mediterranean. Mar. Pollut. Bull. 64, 974-983.

Jany, c., Pairaud, I., Thouvenin, B., Verney, R., 2012. METROC: modélisation idéalisée de substances dissoutes et particulaires rejetées en rade de Marseille. <http:/| archimer.ifremer.fr/doc/00090/20088/>.

Johansson, I., Héas-Moisan, K., Guiot, N., Munschy, C., Tronczyński, J., 2006. Polybrominated diphenyl ethers (PBDEs) in mussels from selected French coastal sites: 1981-2003. Chemosphere 64, 296-305.

Kidd, K.A., Hesslein, R.H., Ross, B.J., Koczanski, K., Stephens, G.R., Muir, D.C.G., 1998 Bioaccumulation of organochlorines through a remote freshwater food web in the Canadian Arctic. Environ. Pollut. 102, 91-103.

Ko, F.C., Beker, J.E., 1995. Partitioning of hydrophobic organic contaminants to resuspended sediments and plankton in the mesohaline Chesapeake Bay. Mar. Chem. 49, 171-188.

Konat-Stepowicz, J., Kowalewska, G., 2003. PCBs in phytoplankton in the Odra Estuary. Oceanologia 45, 491-506.

Lleonart, J., Maynou, F., 2003. Fish stock assessment in the Mediterranean: state of the art. In: Ulltang, O., Blom, G. (Eds.), Fish Stock Assessments and Predictions: Integrating Relevant Knowledge, Scientia Marina, vol. 67, Suppl. 1, pp. 37-49.

Lu, Z., Fisk, A.T., Kovacs, K.M., Lydersen, C., McKinney, M.A., Tomy, G.T., Rosenburg, B., McMeans, B.C., Muir, D.C.G., Wong, C.S., 2014. Temporal and spatial variation in polychlorinated biphenyl chiral signatures of the Greenland shark (Somniosus microcephalus) and its arctic marine food web. Environ. Pollut. 186, 216-225. 
Magnusson, K., Magnusson, M., Ostberg, P., Granberg, M., Tiselius, P., 2007. Bioaccumulation of C-14-PCB 101 and C-14-PBDE 99 in the marine planktonic copepod Calanus finmarchicus under different food regimes. Mar. Environ. Res. 63, 67-81.

Martinez, A., Wang, K. Hornbuckle, K.C., 2010. Fate of PCB congeners in an industrial harbor of Lake Michigan. Environ. Sci. Technol. 44, 2803-2808.

Mcconnaughey, T., Mcroy, C.P., 1979. Food-web structure and the fractionation of carbon isotopes in the bering sea. Mar. Biol. 53, 257-262.

Munschy, C., Moisan, K., Tronczynski, J., 2004. Levels and patterns of PCBs and PCDD/Fs in different tissues of the marine flatfish dab (Limanda limanda) from the English Channel, France. Organohal. Compd. 66, 1695-1703.

Niimi, A.J., Cho, C.Y., 1981. Elimination of hexachorbenzene (HCB) by rainbow trout (Salmo gairdneri), and examination of its kinetics in Lake Ontario salmonids. Can. J. Fish. Aquatic Sci. 38, 1350-1356.

Nizzetto, L., Gioia, R., LI, J., Borgå, K., Pomati, F., Bettinetti, R., Dachs, J., Jones, K.C. 2012. Biological pump control of the fate and distribution of hydrophobic organic pollutants in water and plankton. Environ. Sci. Technol. 46, 3204-3211.

Pinazo, C., Fraysse, M., Doglioli, A., Faure, V.M., Pairaud, I., Petrenko, A., Thouvenin, B., Tronczynski, J., Verney, R., Yohia, C., 2013. MASSILIA: Modélisation de la baie de Marseille: Influence des apports Anthropiques de la métropole sur l'écosystème marin. <http://archimer.ifremer.fr/doc/00145/25592/>.

Plante-Cuny, M.-R., Bodoy, A., 1987. Biomasse et production primaire du phytoplancton et du microphytobenthos de deux biotopes sableux (Golfe de Fos, France). Oceanol. Acta 10, 223-237.

Radakovitch, O., Roussiez, V., Ollivier, P., Ludwig, W., Grenz, C., Probst, J.L., 2008. Input of particulate heavy metals from rivers and associated sedimentary deposits on the Gulf of Lion continental shelf. Estuar. Coast. Shelf. Sci. 77, 285295.

Rasmussen, J.B., Rowan, D.J., Lean, D.R.S., Carey, J.H., 1990. Food-chain structure in Ontario lakes determines PCB levels in lake trout (Salvelinus-Namaycush) and other pelagic fish. Can. J. Fish. Aquat. Sci. 47, 2030-2038.
Rolff, C., 2000. Seasonal variation in delta C-13 and delta N-15 of size-fractionated plankton at a coastal station in the northern Baltic proper. Mar. Ecol. Prog. Ser. 203, 47-65.

Ross, P.S., Ellis, G.M., Ikonomou, M.G., Barrett-Lennard, L.G., Addison, R.F., 2000. High PCB concentrations in free-ranging Pacific killer whales, Orcinus orca: Effects of age, sex and dietary preference. Mar. Pollut. Bull. 40, 504-515.

Saiz, E., Calbet, A., Atienza, D., Alcaraz, M., 2007. Feeding and production of zooplankton in the Catalan Sea (NW Mediterranean). Prog. Oceanogr. 74, $313-$ 328.

Sauzade, D., Andral, B., Gonzalez, J., Galgani, F., Grenz, C., Budzinski, H., Togola, A., Lardy, S., 2007. Synthèse de l'état de la contamination chimique du golfe de Marseille. Agence de l'Eau Rhône Mediterranée et Corse Ed., Marseille, p. 123.

Sauzade, D., Andral, B., Gonzalez, J.-L., Pairaud, I., Verney, R., Zebracki, M., Cadiou, J.F., Boissery, P. 2009. Pressions et état de la contamination chimique marine dans le voisinage d'une grande ville côtière méditerranéenne, le cas de Marseille/Pressure and state of the marine chemical contamination in the vicinity of a large coastal Mediterranean city, the case of Marseilles. Impact of large coastal Mediterranean cities on marine ecosystems - Alexandria, Egypt 10-12 February 2009. <http://archimer.ifremer.fr/doc/00070/18164/>

Sobek, A., Reigstad, M., Gustafsson, O., 2006. Partitioning of polychlorinated biphenyls between arctic seawater and size-fractionated zooplankton. Environ. Toxicol. Chem. 25, 1720-1728.

Taylor, W.D., Carey, J.H., Lean, D.R.S., Mcqueen, D.J., 1991. Organochlorine concentrations in the plankton of lakes in southern Ontario and their relationship to plankton biomass. Can. J. Fish. Aquat. Sci. 48, 1960-1966.

Vousdoukas, M.I., Verney, R., Dufois, F., Pinazo, C., Sauzade, D., Meule, S., Cann, P., Plomaritis, T.A., 2011. Sediment dynamics in the Bay of Marseille, Gulf of Lions (France): hydrodynamic forcing vs. bed erodibility. J. Coastal Res. 27, 942958. 